\title{
PEMANFAATAN MEDIA SOSIAL DALAM PEMBELAJARAN DI SDIT AT-TAQWA SURABAYA
}

\author{
Nadia Risya Faridah ${ }^{1}$, dan Nasihkol Haromain ${ }^{2}$ \\ ${ }^{1,2}$ Pendidikan Guru Madrasah Ibtidaiyah, Pascasarjana, UIN Sunan Ampel Surabaya, Indonesia \\ nadiarisya37@gmail.com
}

Naskah diterima: 3 Juli, 2021, direvisi: 5 Agustus, 2021, diterbitkan: 30 September, 2021

\begin{abstract}
The development of increasingly sophisticated technology makes the world of education evolve to be more flexible. Social media was chosen as one of the efforts of educational institutions to carry out online learning during the Covid-19 pandemic. This research aims to determine the use of social media in learning at the elementary school level, the potential of social media in learning and the advantages and disadvantages of social media in learning. The results of the research show that social media in learning are Zoom Meeting, WhatsApp, YouTube and Instagram which have the potential to increase students' interest and motivation to more respect about assignments. In its implementation, there are advantages and disadvantages to social media when used in learning, therefore the assistance of teachers and parents is very necessary.
\end{abstract}

Keywords: covid-19, social media, learning.

\begin{abstract}
ABSTRAK
Perkembangan teknologi yang semakin canggih membuat dunia pendidikan berevolusi menjadi lebih luwes. Sosial media dipilih menjadi salah satu upaya lembaga pendidikan untuk melaksanakan pembelajaran daring pada masa pandemi Covid-19. Penelitian ini bertujuan untuk mengetahui pemanfaatan sosial media dalam pembelajaran di jenjang sekolah dasar, potensi sosial media dalam pembelajaran serta kelebihan dan kelembahan sosial media dalam pembelajaran. Metode penelitian ini menggunakan pendekatan kualitatif deskriptif dan pengumpulan data dilakukan dengan menggunakan wawancara dan observasi. Hasil penelitian menunjukan bahwa sosial media dalam pembelajaran adalah Zoom Meeting, WhatsApp, Youtube dan Instagram yang berpotensi meningkatkan minat dan motivasi peserta didik untuk lebih peduli terhadap tugas. Dalam pelaksanaannya tak luput dari adanya suatu kelebihan dan kelemahan pada sosial media jika digunakan dalam pembelajaran, oleh karena itu pendampingan guru dan orang tua sangat diperlukan. Kata Kunci: covid-19, media sosial, pembelajaran.
\end{abstract}

\section{Pendahuluan}

Pada era globalisasi, kini setiap lini masyarakat tidak dapat terpisahkan dengan adanya teknologi. Teknologi telah menjadi bagian penting bagi kehidupan masyarakat, baik yang sederhana maupun yang canggih. Revolusi teknologi secara terus-menerus dihadirkan untuk memudahkan dan membantu kegiatan hidup masyarakat. Namun, kehadiran teknologi yang memiliki banyak sekali kontribusi positif ini juga tak luput dengan adanya warna negatif terhadap kehidupan. Kontribusi positif adanya teknologi ini salah satunya terlihat pada sektor pendidikan.

Kontribusi positif adanya teknologi pada sektor pendidikan telah mengubah pola belajar dan pembelajaran yang dilakukan oleh manusia ke arah yang lebih luwes. Setiap individu dapat memanfaatkan media teknologi dan melakukan proses belajar tanpa terikat adanya faktor ruang dan waktu. Tak hanya itu, Pribadi (2017) mengatakan bahwa adanya 
ragam dan variasi jumlah media yang berisi aneka informasi dan pengetahuan yang dapat dipelajari juga merupakan wujud dari perkembangan teknologi. Sehingga peserta didik beserta guru dapat memilih ragam media, informasi dan pengetahuan yang dapat dipelajari sesuai dengan keperluan.

Sejak ditetapkannya teknologi dalam pendidikan dan pembelajaran, upaya mencerdaskan rakyat Indonesia telah dilakukan dengan melaksanakan pembelajaran jarak jauh. Pembelajaran jarak jauh disebut juga dengan Pendidikan jarak jauh merupakan sebuah pembelajaran yang diberikan oleh guru kepada peserta didik secara terpisah, dengan tidak berkumpul bersama dalam satu tempat yang disatukan melalui korespondensi (Safitri \& Astuti, 2019). Di Indonesia, diterapkannya pembelajaran jarak jauh ini bukanlah sesuatu yang baru dikarenakan adanya letak geografis, negara kepulauan dan luasnya negara Indonesia di banding dengan negara lainnya.

Sejalan dengan adanya penerapan pembelajaran jarak jauh, saat ini hal tersebut digunakan sebagai solusi akibat dampak dari pandemi Covid-19. Pandemi Covid-19 yang melanda bangsa kita telah mempengaruhi berbagai sendi kehidupan masyarakat kita, salah satunya adalah kegiatan pendidikan. Adanya hal tersebut pemerintah memberikan anjuran untuk melaksanakan pembelajaran jarak jauh, dimana guru mengajar dari rumah, peserta didik belajar dari rumah dan pembelajaran tatap muka disekolah dihentikan. Sejalan dengan itu, Kementrian Pendidikan dan Kebudayaan menerbitkan surat edaran Nomor 15 Tahun 2020 tentang pedoman Penyelenggaraan Belajar dari Rumah dalam Masa Darurat Penyebaran Covid-19 sebagai acuan lembaga pendidikan dalam melaksanakan kegiatan pembelajaran.

Sejauh ini, pelaksanaan pembelajaran jarak jauh telah banyak digunakan pada Pendidikan Tinggi. Dengan memaksimalkan penggunaan teknologi informasi dan komunikasi, berbagai model pembelajaran jarak jauh dilaksanakan salah satunya dengan pemanfaatan sosial media yang telah tersedia dan dapat digunakan di berbagai platform mulai dari handphone, laptop maupun komputer. Hadirnya sosial media tidak asing lagi bagi masyarakat yang telah biasa digunakan dalam berkomunikasi, berperilaku, bekerja dan berpikir. Terlebih pada peserta didik generasi millenial yang juga termasuk dalam masyarakat digital (digital native).

Media sosial dalam keseharian juga dikenal dengan 'Jejaring Sosial'. Danah M. Boyd dari Sekolah Informasi Universitas California-Berkeley dan Nicole B. Ellison dari Departemen Telekomunikasi Universitas Michigan mengartikan situs jejaring sosial sebagai Layanan berbasis web yang memungkinkan sesorang membangun profil publik atau semipublik dalam sistem yang terbatas tersambung dengan sejumlah pengguna lain untuk saling berhubungan, melihat dan menelusuri sejumlah hubungan mereka yang dibuat oleh orang lain dalam sistem (Fahmi, 2011). Selain itu, media sosial juga diartikan sebagai sebuah media online, dengan para penggunanya bisa dengan mudah berpartisipasi, berbagi, dan menciptakan isi meliputi blog, jejaring sosial, dan wiki. Blog, jejaring sosial dan wiki merupakan bentuk media sosial yang paling umum digunakan oleh masyarakat di seluruh dunia.

Menurut Nasrullah (2015) media sosial merupakan medium di internet yang memungkinkan pengguna dalam mempresentasikan dirinya, berinteraksi, bekerja sama, berbagi, berkomunikasi dengan pengguna yang lain serta membentuk ikatan sosial secara virtual. Hal tersebut didukung oleh data dari survey yang dilakukan oleh Riyanto (2019) pada masa sebelum pandemi masyarakat Indonesia mengakses sosial media menghabiskan hingga 3,5 jam per hari. Artinya, eksistensi media sosial sangat dekat dan sedikit banyak akan berpengaruh dalam kehidupan. Sejalan dengan pernyataan tersebut, Radja Erlan 
Hamzah juga menyatakan dalam penelitiannya yang berjudul "Penggunaan Media Sosial di Kampus dalam Mendukung Pembelajaran Pendidikan" bahwa adanya media sosial dapat menjadi alat pelengkap sistem Pendidikan di Indonesia, khususnya pada jenjang Pendidikan tinggi dikarenakan hampir semua mahasiswa merupakan pengguna teknologi online dan pengguna media sosial (Hamzah, 2015).

Eksistensi penggunaan media sosial dalam pembelajaran jarak jauh ini tidak hanya dilakukan pada jenjang Pendidikan tinggi saja melainkan juga pada jenjang Pendidikan dasar dan menengah, salah satunya terlihat pada penelitian yang dilakukan oleh Kamaludin berjudul "Media Sosial Sebagai Budaya Baru Pembelajaran di SD Muhammadiyah 9 Malang" bahwa penggunaan media sosial memiliki efektivitas yang sangat tinggi karena adanya sebuah aktivitas berulang dapat dilakukan kapan saja, bergantung keinginan pengguna media sosial (Kamaludin, 2020). Keberadaan media sosial yang dapat diakses dengan mudahnya tak hanya menelurkan dampak positif saja melainkan dampak negatif pula sehingga pada jenjang dasar masih perlu adanya controlling dari orang tua dalam pelaksanaan pembelajaran jarak jauh saat ini. Adapun situs media sosial yang banyak digunakan adalah Facebook, Instagram, Whatsapp, YouTube, LINE dan lain-lain.

Diterapkannya pembelajaran jarak jauh dengan memanfaatkan adanya sosial media ini juga ditemui oleh peneliti pada salah satu sekolah dasar di Surabaya yakni SDIT At-Taqwa Surabaya. Dampak dari adanya Covid-19 yang hingga kini belum berujung adalah salah satu alasan utama para pendidik di SDIT At-Taqwa memanfaatkan sosial media sebagai upaya menanggulangi kebosanan peserta didik dalam proses pembelajaran yang tidak bisa dilaksanakan secara langsung. Menurut Ibu Kartika, selaku Koordinator Jenjang kelas VI menyatakan bahwa dipilihnya sosial media adalah untuk mengatasi kebosanan peserta didik dan memvariasikan proses pembelajaran agar tidak monoton dari handbook yang disusun oleh guru dan buku pegangan kurikulum 2013. Hal tersebut diperkuat oleh Ibu Mamik, selaku kepala sekolah SDIT At-Taqwa yang menuturkan bahwa karakter peserta didik saat ini tidak asing lagi dengan keberadaan gawai/smartphone, dengan adanya permasalahanpermasalahan yang dihadapi terkait kebosanan, kecanduan game online, bermain sosial media hingga lupa waktu sehingga muncul beberapa terobosan baru dalam pelaksanaan pembelajaran dengan mengambil celah pada hal yang disukai oleh peserta didik yakni sosial media.

Sejalan dengan penelitian-penelitian terdahulu dan beberapa hal yang dijumpai oleh peneliti di lapangan terlihat bahwa eksistensi sosial media pada pembelajaran jarak jauh ini menjadi salah satu hal yang dipilih oleh beberapa sekolah dalam melaksanakan proses belajar mengajar disekolah dengan tujuan ketuntasan belajar dapat diraih oleh peserta didik. Melihat adanya fenomena tersebut, sosial media tak hanya memiliki dampak negatif saja, melainkan banyak sekali dampak positif yang berpengaruh pada peserta didik saat ini jika dapat mengelola dengan baik.

Berdasarkan paparan diatas, peneliti tertarik untuk mengambil topik pembahasan "Pemanfaatan Sosial Media dalam Pembelajaran di SDIT At-Taqwa Surabaya". Alasan peneliti mengangkat pembahasan tersebut adalah untuk mengetaui bagaimana implementasi pendidik/guru dalam memanfaatkan sosial media sebagai terobosan baru pada masa pandemi dalam melaksanakan proses pembelajaran yang menarik bagi peserta didik. 


\section{Metodologi}

Penelitian ini menggunakan pendekatan kualitatif dengan jenis penelitian field research (penelitian lapangan). Jenis penelitian field research (penelitian lapangan) merupakan sebuah penelitian yang datanya diambil dan dilakukan di lapangan, seperti lingkungan masyarakat, lembaga maupun organisasi kemasyarakatan dengan menganalisis dan menyajikan data faktual secara sistematik tentang keadaan objek penelitian. Hal tersebut sejalan dengan definisi penelitian kualitatif yakni suatu penelitian yang memunculkan sebuah output data deskriptif berupa kata-kata tertulis atau lisan dari orang-orang dan perilaku yang dapat diamati.

Pelaksanaan penelitian ini dilakukan di SDIT At-Taqwa Surabaya. Adapun alasan pemilihan lokasi tersebut adalah karena salah satu peneliti merupakan salah seorang guru kelas dari sekolah SDIT At-Taqwa Surabaya sehingga memudahkan peneliti dalam hal pengumpulan data. Data yang diperoleh dalam pelaksanaan penelitian ini bersumber dari subjek, informan penelitian serta literatur sebagai pendukung teori yang bersifat ilmiah. Subjek yang dipilih dalam penelitian ini adalah guru kelas 6 di SDIT At-Taqwa Surabaya. Sedangkan informan dalam penelitian yang dapat memberikan informasi terkait adalah koordinator level 6, guru kelas 6 dan peserta didik.

Adapun instrumen yang digunakan dalam penelitian yakni menggunakan observasi dan wawancara. Observasi dilakukan untuk memperoleh informasi terkait pelaksanaan proses pembelajaran menggunakan media sosial. Kegiatan observasi ini dimaksudkan untuk memperhatikan langsung penggunaan ragam bentuk media sosial yang digunakan oleh guru dalam pelaksanaan proses belajar mengajar di SDIT At-Taqwa Surabaya agar dapat menemukan data, informasi secara langsung dan alamiah dari kegiatan yang berlangsung. Sedangkan wawancara dilakukan untuk memperoleh data bagaimana potensi, kelebihan dan kelemahan yang dirasakan oleh guru dan peserta didik dalam proses belajar mengajar dengan menggunakan media sosial.

Data pada penelitian ini berupa kata-kata, tulisan maupun tingkah laku yang dilakukan oleh para guru dan peserta terkait dengan pemanfaatan media sosial dalam pembelajaran SDIT At-Taqwa Surabaya. Data yang telah terkumpul dianalisis menggunakan teknik analisis yang dikembangkan oleh Miles and Hubberman.

\section{Hasil dan Pembahasan}

\subsection{Pemanfaatan Media Sosial dalam Pembelajaran}

Wabah virus covid-19 telah tersebar di berbagai penjuru dunia, salah satunya di Indonesia. Dalam menghadapi hal tersebut, terdapat beberapa peraturan pemerintah yang diterbitkan guna untuk mencegah tingkat persebaran yang semakin tinggi. Adapun upaya yang tengah digalakkan saat ini adalah social distancing. Social distancing adalah tindakan jaga jarak sosial, seperti menghindari kerumunan, keramaian dan kontak fisik. Adanya upaya tersebut sudah jelas berpengaruh terhadap sektor pendidikan. Pembelajaran tatap muka berganti menjadi pembelajaran daring (dalam jaringan), yang telah digaungkan pula oleh Kementrian Pendidikan dan Kebudayaan dengan mengeluarkan Surat Edaran No. 4 Tahun 2020 tentang Pelaksanaan Kebijakan Pendidikan dalam Masa Darurat Penyebaran Coronavirus Desease (Covid-19). Adanya kebijakan tersebut sebagai salah satu jalan keluar dunia pendidikan dalam menghadapi suatu kondisi yang tidak pernah terbayangkan sebelumnya. Berbagai upaya dilaksanakan untuk memaksimalkan kegiatan proses pembelajaran yang menjadi suatu tantangan tersendiri bagi lembaga pendidikan dalam mengemas hal tersebut. 
Dalam melaksanakan pembelajaran daring ini pendidik harus mampu untuk menyesuaikan diri dengan sarana dan prasarana yang digunakan maupun kebutuhan peserta didik. Seperti yang dinyatakan oleh Handarini \& Wulandari (2020) bahwa guru harus mampu mengembangkan profesi pendidik serta menjalankan tugasnya dengan menyesuaikan pada kebutuhan peserta didik serta mengemas materi pembelajaran sesuai perkembangan zaman. Beragam pelaksanan pembelajaran daring ini dilakukan, namun upaya tersebut tidak luput dari berbagai permasalahan dalam pelaksanaannya, Permasalahan hadir dari pendidik dan juga peserta didik, seperti konten materi yang tersampaikan secara daring belum tentu dapat dipahami oleh peserta didik, terbatasnya kemampuan guru dalam beradaptasi menggunakan berbagai teknologi, keterbatasan guru dalam melakukan controlling terhadap peserta didik, peserta didik cenderung menjadi bosan dan malas dengan kegiatan pembelajaran daring, peserta didik tidak memiliki perangkat handphone/laptop yang digunakan sebagai media belajar daring (Asmuni, 2020). Hal tersebut dapat terjadi karena adanya pengaruh keadaan orang tua peserta didik, seperti perbedaan latar belakang ekonomi orang tua peserta didik, orang tua peserta didik bekerja diluar rumah sehingga menyulitkan untuk controlling terhadap kebutuhan anak belajar dirumah, sehingga orang tua tidak bisa mendampingi dan membimbing peserta didik secara intens di rumah.

Permasalahan tersebut terjadi pada sektor pendidikan, mulai dari pendidikan jenjang dasar, menengah dan tinggi sekalipun. Sejalan dengan paparan di atas, hal itu terlihat pula di SDIT At-Taqwa Surabaya. Ibu Kartika selaku koordinator jenjang kelas 6 memaparkan bahwa yang menjadi permasalahan dalam pelaksanaan pembelajaran daring ini terletak pada kondisi peserta didik meliputi kurangnya antusiasme peserta didik dalam pembelajaran, banyaknya peserta didik yang kurang tanggap saat pengumpulan tugas, kurangnya controlling terhadap gadget yang digunakan oleh peserta didik, beberapa peserta didik kesulitan dalam hal sinyal maupun kuota, keterbatasan orang tua dalam hal pengawasan dan pembimbingan terhadap peserta didik. Melihat kondisi tersebut, beliau juga menambahkan bahwa upaya yang telah dimaksimalkan saat ini adalah penggunaan gamifikasi, Zoom Meeting, jejaring sosial Whatsapp dan LMS Moodle yang telah disiapkan oleh lembaga pendidikan.

Saat ini, masyarakat maupun peserta didik pada berbagai jenjang pendidikan tidak asing lagi dengan adanya sosial media. Dilansir dari data yang dimiliki oleh Hootsuite pada masa sebelum pandemi, rata-rata setiap orang di Indonesia menghabiskan waktu 8 jam mengakses internet dan 3,5 jam dilakukan untuk menggunakan media sosial. Media sosial yang banyak digunakan saat ini adalah YouTube, WhatsApp, Facebook dan Instagram (Riyanto, 2019). Sejalan dengan data tersebut, Ibu Kartika bersama tim melaksanakan evaluasi pada rapat koordinasi jenjang guna menanggulangi permasalahan pada peserta didik. Salah satu solusi yang digunakan adalah memaksimalkan pemanfaatan media sosial, dikarenakan karakteristik peserta didik sangat dekat dengan media sosial yakni WhatsApp, Zoom Meeting, YouTube, dan Instagram.

Menurut Bradley (2010) ada beberapa hal yang dapat membedakan antara media sosial dengan bentuk komunikasi yang lain, yakni:

a. Participation - adanya media sosial bergantung pada kolaborasi massal yang terlaksana melalui partisipasi pengguna (user participation). Para pengguna dapat mengembangkan ide yang dimiliki dengan menggunakan teknologi yang lebih mudah untuk digunakan dibandingkan dengan teknologi yang sudah ada sebelumnya. Contoh: memberikan stimulus kepada pengguna untuk kembali ke sebuah media sosial untuk melanjutkan percakapan yang telah dimulai di kolom komentar. 
b. Collective - terdapat banyak situs media sosial dimana para pengguna dapat mengumpulkan informasi dengan tujuan membentuk ulang konten yang telah tersedia dan mempublikasikannya ke publik dengan fitur berbagi di situs tersebut. Tak hanya itu, pengguna juga dapat menggunakan fasilitas yang ditawarkan dengan kemampuan system atau software untuk bertukar informasi menggunakan aplikasi yang tersedia untuk mengakses informasi yang tersimpan secara online di situs media sosial lain.

c. Transparency - konten yang telah dibuat dapat disebarkan ke publik melalui komentar, vote, dan lain sebagainya. Bahkan ketika terdapat kemungkinan untuk menyimpan atau memiliki konten online yang bersifat pribadi, hanya arus informasi dan konten yang transparan yang akan berperan dalam collaborative participation.

d. Independence - pengguna dapat berpartisipasi dengan bebas kapanpun, dari mana saja, dan dimana saja yang mereka inginkan. Karakteristik media sosial terkait pada arus konten yang bebas dan menyebar cepat melalui jaringan internet.

e. Persistence - konten digital yang terpubikasi akan tetap tersedia seiring berjalannya waktu sebagai reputasi yang muncul terhadap suatu hal. Oleh karena itu, sebagian besar orang akan berpikir bahwa dia akan selalu dikenal sebagai anonym di internet.

f. Emergence - sebagian besar masyarakat menyetujui bahwa media sosial merupakan bagian penting dari ranah digital saat ini dan di masa mendatang. Namun, terdapat pula pendapat yang mengatakan bahwa media sosial tidak pernah dapat diprediksi secara keseluruhan dan tidak terjamin kepastiannnya.

Dengan memanfaatkan media sosial yang telah disebutkan pendidik dituntut untuk mengemas proses pembelajaran dengan menarik hingga pengumpulan tugas maupun mengevaluasi kemampuan peserta didik terhadap ketuntasan suatu materi pembelajaran. Pemanfaatan sosial media di SDIT At-Taqwa Surabaya membawa hasil sebagaimana berikut ini.

Tabel 1. Media Sosial dan Pemanfaatannya

\begin{tabular}{|c|c|}
\hline Zoom Meeting & $\begin{array}{l}\text { Sebagai jejaring sosial primer yang digunakan } \\
\text { untuk tatap muka online antara guru dan peserta } \\
\text { didik. }\end{array}$ \\
\hline WhatsApp & $\begin{array}{l}\text { Sebagai tempat sumber informasi utama, tim guru } \\
\text { membuat informasi dalam satu pekan terkait } \\
\text { kegiatan yang akan dilaksanakan oleh peserta } \\
\text { didik. Terkait materi pembelajaran dihimpun } \\
\text { pada LMS (Learning Management System) } \\
\text { Moodle yang telah disediakan oleh lembaga } \\
\text { Pendidikan. }\end{array}$ \\
\hline YouTube & $\begin{array}{l}\text { - Sebagai sumber belajar tambahan bagi peserta } \\
\text { didik yang dimaksudkan untuk peserta didik } \\
\text { yang tidak dapat mengikuti kegiatan } \\
\text { pembelajaran pada jadwal yang ditentukan. } \\
\text { Dalam hal ini, peserta didik setiap hari } \\
\text { melaksanakan kegiatan tatap muka online } \\
\text { melalui Zoom Meeting dan dapat mengakses } \\
\text { materi dilain waktu. }\end{array}$ \\
\hline
\end{tabular}




\begin{aligned} & \hline- Sebagai sarana pengumpulan penilaian \\ & keterampilan pada mata pelajaran tertentu, \\ & misalnya: membuat karya, menari, presentasi \\ & materi, dsb. \\ &- Sebagai output dari kegiatan yang \\ & dilaksanakan menggunakan Zoom Meeting \\ & dan diolah menggunakan OBS Studio, \\ & misalnya: virtual tour, pelatihan, kegiatan \\ & akhir semester, dsb. \\ & \hline - Sebagai sumber informasi terkait kegiatan \\ & pembelajaran di sekolah secara umum. \\ &- Sebagai sarana pengumpulan yang berkaitan \\ & dengan literasi (menceritakan kembali buku \\ & yang telah dibaca dilaksanakan setiap pekan), \\ & hafalan khas At-Taqwa (doa dan hadits yang \\ & berkaitan dengan tema besar sesuai kurikulum \\ & visi semesta), dan potret life skill yang telah \\ & ditentukan oleh tim guru. \\ & Dalam hal ini, peserta didik diperkenankan \\ & untuk saling share dan comment sesuai etika \\ & dalam menggunakan media sosial pada \\ & postingan yang telah diunggah, sehingga \\ & peserta didik tidak merasa terbatasi. \end{aligned}

\subsection{Potensi Media Sosial dalam Pembelajaran}

Berdasarkan paparan diatas, media sosial yang dipilih untuk keberlangsungan proses pembelajaran yakni Zoom Meeting, WhatsApp, YouTube dan Instagram. Dalam mengimplementasikan hal tersebut dalam pembelajaran ada beberapa hal yang perlu dipertimbangkan yakni: (1) menentukan tujuan apa yang ingin dicapai, sehingga pemilihan sosial media tepat sasaran. (2) memperhatikan kepada siapa kita akan berkomunikasi. (3) mempertimbangkan bentuk pesan yang dikirimkan agar tidak terjadi miskonsepsi antara tim guru, peserta didik dan orang tua yang mendampingi di rumah.

Perkembangan media terutama media sosial akhir-akhir ini luar bisa masif. Hampir semua bidang telah dimasuki oleh media sosial sebagai perantara berkomunikasi manusia, begitu pula di bidang pendidikan. Anthony Giddens mengumpamakan keadaan seperti ini sebagai 'juggernuts' yang siap kapan saja melibas kondisi yang tidak mau berubah. AECT (Association of Education and Communication Technology) membatasi media sebagai segala bentuk dan saluran yang digunakan untuk menyampaikan pesan atau informasi. Biasanya istilah ini diganti dengan 'mediator' yang menurut Fleming (1987) adalah penyebab atau alat yang ikut campur dalam dua pihak dan mendamaikannya. Sehingga istilah mediator media menunjukkan fungsi atau perannya untuk mengatur hubungan efektif antara dua pihak utama dalam proses belajar siswa dan isi pelajaran. Mediator dapat pula mencerminkan pengertian bahwa setiap sistem pembelajaran yang melakukan peran mediasi, mulai dari guru sampai kepada peralatan yang paling canggih bisa disebut media. Jadi media merupakan alat yang menyampaikan atau mengantarkan pesan-pesan pembelajaran (Kamaludin, 2020). 
Pemanfaatan media jejaring sosial seperti Facebook, instagram, Whatsapp dan lainnya untuk mengakses media pembelajaran bukanlah hal baru dan telah diteliti efektifitasnya, serta pro dan kontranya. Senantiasa ada aspek pro dan kontra untuk sebuah inovasi, namun pemanfaatan media sosial sebagai media pembelajaran adalah sebuah inovasi yang menantang. Kekuatan dari media sosial pada era digital ini sangat luar biasa, sehingga media sosial sangat potensial dikembangkan untuk pembelajaran.

Media sosial merupakan sarana potensial untuk menciptakan seatu pembelajaran yang efektif. Memanfaatkan media sosial sebagai sarana untuk refleksi, sarana untuk memperoleh umpan baik dari mitra bestari, dan sarana untuk berkolaborasi dalam pembelajaran. Aspek yang menarik dari media sosial adalah banyak anak muda yang mengenal baik dan pengguna setianya. Selanjutnya media sosial menjadi sarana untuk tujuan sosialisasi dimana interaksi antara guru dan siswa terjadi dan berlangsung secara efektif dan bersifat informal. Namun demikian pemanfaatan media sosial untuk tujuan formal belum banyak digunakan.

Terlebih lagi pada masa pandemi Covid-19 ini, banyak lembaga pendidikan yang dalam proses pembelajarannya juga mengikuti arahan dari Surat Edaran Kemendikbud, yaitu melalui pembelajaran daring/jarak jauh dengan cara memanfaatkan media sosial yang ada, seperti Facebook, Youtube, Whatsapp, Instagram, Zoom, Ruang Guru, dan platform dari Kemenag yaitu E-Learning. Para guru dan orang tua dituntut agar mampu memanfaatkan media sosial dalam proses siswa belajar dari rumah. Sehingga dalam proses pelaksanaannya masih terdapat kendala. Sebab, tidak semua siswa terbiasa belajar melalui online. Apalagi guru dan orang tua masih banyak belum mahir menggunakan teknologi internet dan media sosial.

Selama pelaksanaan pembelajaran daring dengan memanfaatkan media sosial tersebut, peserta didik tidak mengeluh bosan dan antusias dalam hal pengumpulan tugas yang terlihat pada data pada salah satu kelas di jenjang kelas 6 yakni 20 dari 27 peserta didik mengumpulkan dengan tepat waktu dan 7 lainnya perlu diingatkan dan dikarenakan kendala gadget yang digunakan oleh orang tua bekerja. Melihat data tersebut, pemanfaatan sosial media dalam proses pembelajaran berpotensi dapat meningkatkan minat dan motivasi peserta didik untuk lebih respect terhadap tugas yang diberikan guna pemenuhan laporan penilaian. Menurut peneliti, dengan memahami kondisi lapangan tersebut pemanfaatan media sosial yang dapat diakses dimanapun ini menjadi efektif pula meskipun dilanjutkan pada masa pandemi Covid-19 telah usai.

\subsection{Kelebihan dan Kelemahan Sosial Media dalam Pembelajaran}

Pemanfaatan sosial media yang digunakan untuk berlangsungnya kegiatan pembelajaran terdapat beberapa kelebihan yang tak luput juga dengan adanya kelemahan. Hal tersebut diuraikan sebagai berikut.

Kelebihan:

1. Berpotensi untuk digunakan sebagai sarana pembelajaran

2. Merangsang peserta didik untuk belajar lebih mandiri.

3. Peserta didik dapat mengembangkan potensi kreativitas yang dimiliki

4. Dapat meningkatkan minat peserta didik dalam pembelajaran

5. Meningkatkan efektivitas dalam proses pembelajaran

6. Eksistensi sosial media telah dekat dengan peserta didik, sehingga tidak perlu beradaptasi terlalu lama.

7. Lebih banyak variasi dalam proses pembelajaran. 
Kelemahan:

1. Cenderung membuat peserta didik lupa waktu dalam penggunaan media sosial

2. Kondisi gadget yang tidak sama antar peserta didik

3. Apabila kurang controlling dari orang tua, maka peserta didik akan menjadi kecanduan

4. Kurangnya interaksi secara langsung antar peserta didik

5. Penggunaan gadget terlalu lama dapat mempengaruhi kesehatan peserta didik.

\section{Kesimpulan}

Pemanfaatan sosial media dalam pembelajaran merupakan salah satu terobosan atau solusi yang dihadirkan untuk mengatasi beberapa permasalahan dalam pelaksanaan pembelajaran berbasis dalam jaringan. Permasalahan tersebut hadir dari peserta didik dan guru sekalipun seperti kurangnya antusiasme peserta didik dalam pembelajaran, banyaknya peserta didik yang kurang tanggap saat pengumpulan tugas, kurangnya controlling terhadap gadget yang digunakan oleh peserta didik, beberapa peserta didik kesulitan dalam hal sinyal maupun kuota, keterbatasan orang tua dalam hal pengawasan dan pembimbingan terhadap peserta didik. Oleh karena hal tersebut, para pendidik di SDIT At-Taqwa Surabaya menghadirkan sosial media sebagai bentuk solusi yang digunakan karena dekat dengan peserta didik.

Adapun media sosial yang digunakan adalah Zoom Meeting, WhatsApp, YouTube dan Instagram yang berpotensi meningkatkan minat peserta didik dalam pengumpulan tugas dan lebih respect terhadap pembelajaran. Dalam pelaksanaan itu tak luput dari adanya suatu kelebihan dan kelemahan pada sosial media jika digunakan dalam pembelajaran, oleh karena itu disamping guru perlu ada support dari orang tua peserta didik agar pengaruh negatif dapat di minimalisir.

Penelitian ini telah dilaksanakan sesuai dengan prosedur ilmiah pada lingkup satu kelas dengan jenjang yang sama. Hal tersebut yang menjadi keterbatasan dalam penelitian ini, sehingga peneliti memberikan rekomendasi untuk penelitian selanjutnya dengan fokus yang sama, yakni: memperluas responden peserta didik tidak hanya satu kelas saja melainkan pada keseluruan dengan jenjang yang sama, menambahkan responden dari sisi orang tua/wali murid dalam mendampingi peserta didik guna mengetahui kendala apa yang dihadapi serta solusinya, dan mengungkap secara detail pemanfaatan sosial media dalam pembelajaran yang dikaitkan dengan proses pembelajarannya.

\section{Daftar Pustaka}

Asmuni. (2020). Problematika Pembelajaran Daring di Masa Pandemi Covid-19 dan Solusi Pemecahannya. Jurnal Paedagogy: Jurnal Penelitian Dan Pengembangan Pendidikan, 7(4), 281-288.

Hamzah, R. E. (2015). Penggunaan Media Sosial di Kampus Dalam Mendukung Pembelajaran Pendidikan. Jurnal Wacana, XIV(1), 45-70. http://journal.moestopo.ac.id/index.php/wacana/article/view/89

Handarini, O. I., \& Wulandari, S. S. (2020). Pembelajaran Daring Sebagai Upaya Study From Home ( SFH) Selama Pandemi Covid 19 Pembelajaran Daring Sebagai Upaya Study From Home ( SFH) ... .. 8(1), 496-503.

Kamaludin, M. (2020). Media Sosial sebagai Budaya Baru Pembelajaran di SD Muhammadiyah 9 Malang Jurnal Komunikasi Nusantara. Jurnal Komunikasi Nusantara, 2(1), 17-27. 
Nasrullah, R. 2015. Media Sosial Prespektif Komunikasi, Budaya, dan Sosioteknologi, (Bandung: Simbiosa Rekatama Media)

Riyanto, A. D. (2019). Hootsuite (We are Social): Indonesian Digital Report 2019. Andi.Link. https://andi.link/hootsuite-we-are-social-indonesian-digital-report-2019/

Pribadi, Benny A., 2017, Media dan Teknologi dalam Pembelajaran, (Jakarta: Prenada Media)

Safitri, A., \& Astuti, J. (2019). Keefektifan Pembelajaran Jarak Jauh. 